\title{
The Role of Modern Economics in the Improvement of Enterprise Management Efficiency
}

\author{
Shang Yu \\ School of economics, Shandong University of Finance and Economics, Jinan, 277100, China \\ Email:893734807@qq.com
}

\begin{abstract}
Now in the 21st century, the management of Chinese enterprises mainly includes financial management, production management, human resource management and other management modes. Corporate management and corporate management efficiency directly affect the development of enterprises. If enterprises want to develop faster and better, they must pay attention to and do a good job in these two aspects. After years of repeated research, it is found that modern economics has a significant effect on the management of enterprises and the benefits of enterprise management. Modern economics can make overall analysis of corporate management and corporate management benefits, and can improve corporate management and enhance corporate management benefits. Modern economics is the macro guidance for business management decision-making. In the process of business management, managers can make correct, scientific and reasonable decisions based on the theories and knowledge of modern economics. This article discusses the status quo of Chinese corporate management efficiency and analyzes the role of modern economics in corporate management efficiency. Through analysis, it is found that modern economics can improve the management efficiency of enterprises. Therefore, it is necessary for enterprises to bring modern economics into enterprise management.
\end{abstract}

Keywords: Modern economics, business management, efficiency, economic principles

\section{INTRODUCTION}

For enterprises nowadays, modern economics has fundamentally changed the management of enterprises [1]. Modern economics has become a basic strategic guidance for enterprises. It has an inestimable market value for helping enterprises to discover changes in market demand in a timely manner, predicting industry development trends, and improving enterprise management efficiency and management benefits. Compared with traditional economics, modern economics is a new type of discipline that includes sociology, psychology, brain science and other theoretical knowledge [2]. Modern economists try to use the perspective of integration of multiple disciplines to interpret why companies often make choices that are contrary to the best corporate management efficiency. This type of behavioral research aims to more efficiently, scientifically, and correctly guide the design of corporate management for accurate public management intervention. Over the years, modern economics has been widely used in many fields such as corporate management and financial regulations.
Because of the strong practical effects of modern economics, more and more companies are paying attention [3].

Modern economics is a discipline that guides how to conduct business management and how to improve the efficiency of business management. It has a very important guiding role in business management and business management benefits [4]. With the rapid development and deepening of economic globalization and the transition of China's market economy, the development of domestic enterprises at this stage is facing fierce market competition. Therefore, in such a fiercely competitive environment, the decision-making ability and strategic planning ability of enterprise decision-makers are the key factors for the long-term development of enterprises [5]. Modern economics is a market-oriented economic reform and opening up. It is the direct force that has promoted fundamental changes in economics as a social science in China in the past two decades. Among them, the principles and theoretical knowledge of demand law, price law, price elasticity and cost analysis in modern economics play a guiding 
role in the development of business management and the development of business management efficiency. Modern economics is an important basis for grasping the direction of business development [6]. Corporate management and corporate management benefits are an important basis for making correct corporate strategic decisions. It can guide corporate decision-makers to follow corporate management rules and make correct, scientific and reasonable decisions.

In the process of internal operation of modern enterprises, corporate management is the most important part. Corporate management involves all aspects of a company's employees, operations, taxation, capital, etc., and whether the management of these aspects is scientific for the production and operation of the company It has a direct influence [7]. The efficiency of enterprise management is the key to the development of an enterprise, and the future survival and development of an enterprise will be carried out on the basis of the efficiency of enterprise management. The management of the enterprise can fully guarantee the economic benefits of the enterprise [8]. Enterprises should attach importance to enterprise management and manage enterprises scientifically and rationally. If an enterprise wants to realize the sustainable development of the enterprise in the fierce market competition, it must strengthen the management of the enterprise, so as to form a more subjective binding force in the development of the enterprise and strengthen the management of the enterprise. Funds and personnel [9]. Only in this way can we fundamentally improve the management ability of the enterprise and directly improve the management efficiency of the enterprise [10].

\section{METHOD}

\subsection{Strengthen the core management of the enterprise and improve the management efficiency of the enterprise}

As we all know, it is necessary to make detailed solutions and measures for some problems in management of enterprises, so as to ensure the stable and sustainable development of enterprise management. Relevant management departments should also make detailed predictions on the development of the enterprise, and take corresponding preventive measures in the development, risk, investment, taxation, and personnel of the enterprise to prevent emergencies. In the process of normal operation of the enterprise, it is necessary to resolutely implement the management system of enterprise management, to formulate plans for the development of the enterprise, and not to shrink back when encountering the shortcomings of enterprise management. You must be brave to overcome the difficulties and overcome the difficulties. Give full play to the role of prevention. When considering some objective or non-objective conditions, the future development of the company must be taken as the prerequisite for consideration, and the future development, decision-making, investment, personnel and other aspects of the company must be predicted. Detailed management plan.

\subsection{Improve the management model of the enterprise}

To improve the corporate management system and standardize corporate management and management systems, it is necessary to realize the transformation and upgrading of corporate management structure, rationally allocate corporate management powers and responsibilities, and formulate comprehensive strategic objectives based on corporate development, strategic objectives and operating risks. Secondly, in accordance with the principles of modern economics and the regulations and requirements of the enterprise management system, specialized management departments should collect and sort out information related to enterprise management in a timely and accurate manner, strengthen effective communication within the enterprise, and make the efficiency of enterprise management consistent with the modern economics of the enterprise. Produce the connection, put modern economics through the whole process of business management, and adopt corresponding management measures to control the development of the enterprise within the tolerance. In addition, it is necessary to follow the scientific, reasonable and correct principles of modern economics to make reasonable adjustments to the management mode of the enterprise, strengthen the efficiency of enterprise management, and establish a scientific and effective enterprise management mode.

\subsection{Carry out education and training to enhance corporate management efficiency}

At this stage, it cannot be said that all enterprises in China have a perfect corporate management system, which needs to be strengthened and updated so as to maintain the sustainable development of the enterprise and make the enterprise go higher, longer and longer. Comprehensively improve the overall management level of enterprise management and managers, comprehensively promote the ideological principles of modern economics, and conduct in-depth study and understanding. In a sense, modern economics is a science of choice. From the perspective of an enterprise, it guides the enterprise to pursue maximization under constraints and under normal circumstances, the slope of the demand curve is negative. The basic principle is to make choices or decisions on business management and management benefits. Modern economics has developed into a huge subject with many branches, some of which 
constitute the teaching content of certain aspects of business management training, and some of the branches are integrated into certain aspects of business management or training in certain aspects of management ability among.

\section{EXPERIMENT}

\subsection{Subject}

It is well known that the effectiveness of corporate management is an important indicator to measure the management level and technical capabilities of an enterprise. As an important basic industry of my country's national economy, iron and steel enterprises have higher requirements on the management system and management efficiency of enterprise management. This chapter takes iron and steel enterprises as the experimental object, according to the actual situation of enterprise management, combined with the theoretical methods of modern economic management, to implement improvements to the main problems in enterprise management and improve the management efficiency of enterprises. In recent years, with the intensification of market competition and the increase in product quality requirements of customers, the company's product quality level has not been able to meet the needs of the market, and many quality problems have occurred. These quality problems include both subjective and objective reasons. Causes; including not only caused by changes in the external environment, but also caused by poor corporate management. This has led to a continuous decline in the management efficiency of enterprises. Therefore, to implement business management in enterprises, improve business management systems, learn modern economics, find out the causes of occurrences, tap the potential to improve management benefits, continuously improve the management benefits of enterprises, and ensure the perfect combination of theory, practice, and benefits. Become the main problem facing the company.

\subsection{Experimental design}

The research methods used in this article include:

(1) Literature research method: Through a large number of searches and reading domestic and foreign literature related to this article, understand the specific content of modern economics and various methods of business management, and prepare for further research.

(2) Quantitative analysis method: This article collects a large amount of data through WTO, UNCTAD, WORLDBANK and other databases, and conducts a quantitative analysis of Chinese and international corporate management and corporate management income to provide a basis for related research.
(3) Normative analysis method: This article analyzes the collected data, discovers the connection between modern economics and business management income, and uses normative analysis to evaluate the effect of modern economics on business management income.

\section{RESULTS}

\subsection{Investigation and analysis of experimental data}

With the increasing pressure of market competition and the increase of customer quality expectations, the quality income of enterprises gradually declines. Therefore, there is an urgent need to invest in quality to strengthen the management of product quality by corporate management, implement corporate management improvements, and improve quality benefits. According to the scientific and reasonable theory in modern economics, the enterprise management shall be restructured and corresponding measures shall be taken. According to the characteristics of quality assurance cost in reducing quality loss cost and improving quality level, combining with the quality requirements of customers, in the design stage, follow the analysis The quality investment goal of the company is to invest in the following investment in enterprise management operations: 1) Strengthen the investment in the review of management design schemes, and solve the hidden quality problems from the drawings; 2) Strengthen the strict review of the supplier' $\mathrm{s}$ qualifications, and strengthen the inspection of raw materials It is necessary to establish a supplier database to record the quality of suppliers' products; 3) Strengthen management quality inspection and analysis during the production process, and also need to conduct regular inspections of production equipment to ensure the normal operation of the machine, increase employee skill training, and develop a management and operation specification system 4) Add high-performance testing equipment to improve testing accuracy and shorten the identification period. 


\subsection{Experimental investigation results}

\subsubsection{Quality investment analysis}

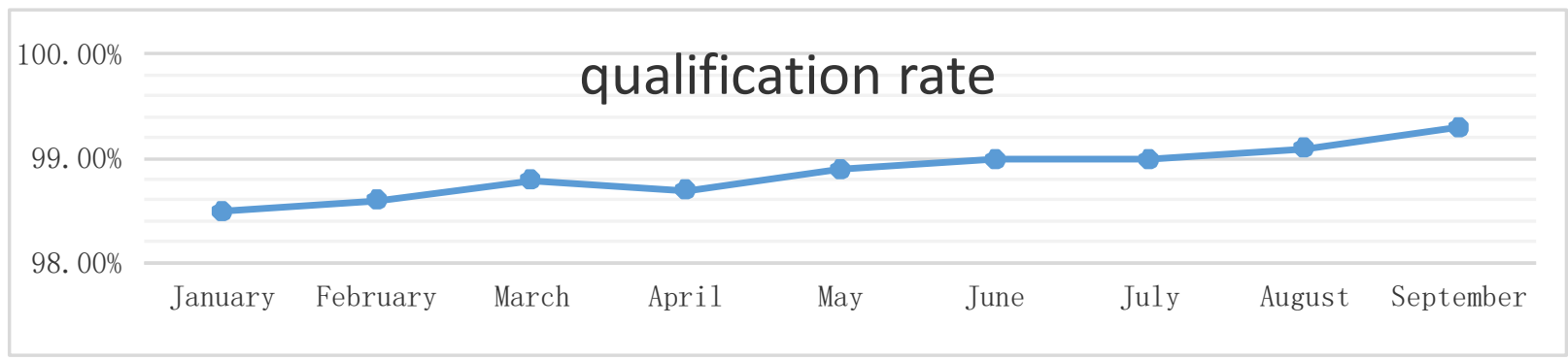

Figure 1 Trend of product qualification rate

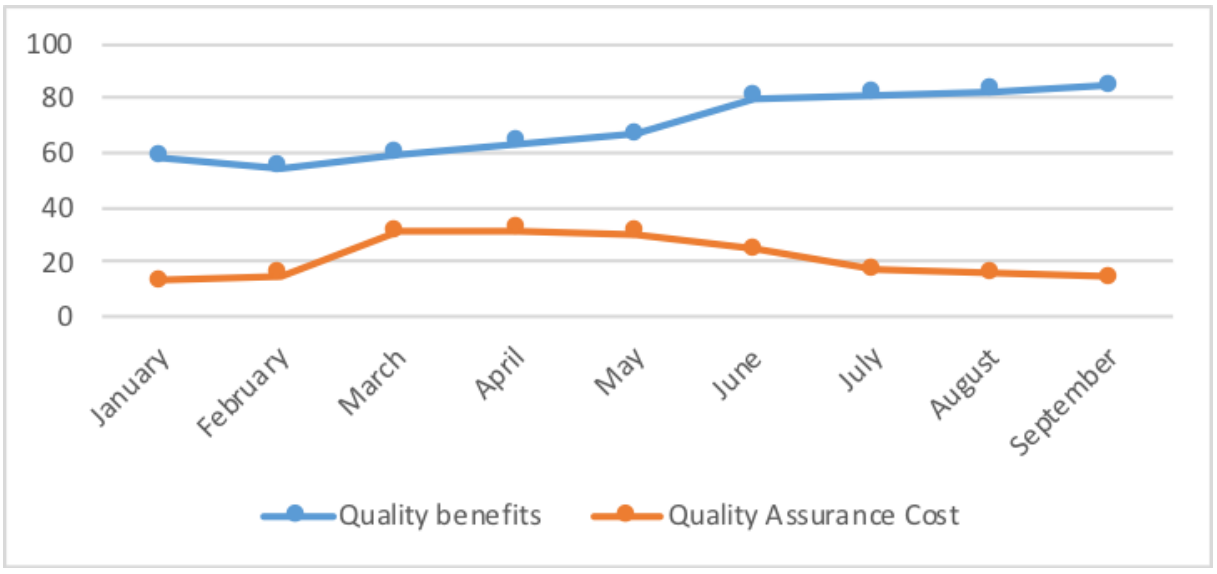

Figure 2 Quality assurance costs and quality benefit costs

It can be seen from Figure 1 that the product qualification rate hovered around $98.5 \%$ before the implementation of the improvement of corporate management efficiency in January 2017. Enterprises have entered into the research on modern economic theory and knowledge and decided to invest above and start to implement management reforms in February 2017. It can be seen from Figure 2 that the company has increased its investment in quality assurance costs for three consecutive months starting in March, and the investment has remained at an average of 300,000 yuan/month. The investment began to pay off in April. During the month, its yield rate increased steadily month by month, from the initial $98.5 \%$ to $99.3 \%$ in September and stabilized at about $99.3 \%$, with good results. The quality gains did not increase significantly in the first three months of quality investment due to the lack of timely response from the market, but starting from June, the effects of quality improvement gradually took effect, and the gains from high-quality quality soared to 800,000 yuan per month. An increase of one-third compared to before the improvement. It can be seen from Figure 2 that when the product qualification rate reaches more than $99 \%$, the company's investment in quality assurance costs is decreasing, from about 301,000 yuan in May to about 145,000 yuan in September.

\subsubsection{Summary analysis of quality and economic benefits}

Through the above analysis, the data of quality assurance cost, quality loss cost, total quality cost, quality benefit and quality economic benefit are summarized into a table.

Table 1 Summary of Quality and Economic Benefits

\begin{tabular}{|c|c|c|c|c|c|c|}
\hline & January & February & March & April & May & June \\
\hline Quality loss cost & 52.3 & 52.4 & 50.3 & 34.5 & 27.1 & 25.6 \\
\hline Total quality cost & 65.5 & 67.4 & 81.5 & 66.3 & 57.2 & 49.9 \\
\hline Quality benefits & 58.3 & 54.7 & 59.6 & 63.2 & 66.5 & 80.2 \\
\hline Quality economic benefits & -8.2 & -12.7 & -21.9 & -3.1 & 9.3 & 30.3 \\
\hline
\end{tabular}


As shown in Table 1. It can be found from Table 1 that January to February is the preparation stage for quality improvement. The average product pass rate is $98.55 \%$, the quality cost remains high, the quality benefit grows slowly, and the quality economic benefit even shows a negative growth. According to this situation, the company has implemented quality improvement for three consecutive months starting in March. By formulating preliminary plans in accordance with the principles of modern economics, it has doubled its investment in quality assurance costs, paying attention to customer quality needs, and actively driving quality assurance costs. The cost of loss has dropped sharply, and the decrease in the cost of quality loss is greater than the investment in quality assurance costs, which makes the quality cost overall a downward trend; under the effect of the decline in quality costs, the economic benefits of quality have shown an upward trend, and a positive return was realized in May. When entering the quality improvement stage, the average product pass rate exceeded $99.3 \%$. Since June, the quality assurance cost has gradually fallen to the quantity before the quality improvement, and the cost of quality loss has declined slowly; but driven by the increase in quality gains, the quality economy Benefits are still on the rise. Through the empirical analysis of quality and economic benefits data, it is concluded that implementing customized business management under the principles of modern economics and timely and reasonable quality investment can not only improve the quality level but also increase the quality and economic benefits, and ensure the continuous profitability of the enterprise.

\section{CONCLUSION}

It is very necessary for modern economics to apply the management principles and theoretical knowledge of modern economics to the practice of business management. It can not only promote the maximization of business management benefits, but also guide the sustained and healthy development of the business economy. This article first discusses the benefits of modern economics and business management in detail, expounds the connection between modern economics and business management, expounds the status quo and development trend of business management under the new situation, and summarizes the methods and methods to improve business management benefits. The relevant theories of modern economics, based on the current research results, combined with the characteristics of modern economics, put forward the ideas of how to improve the efficiency of business management. Then, it conducts an in-depth discussion on modern economics and business management framework, and through the analysis of modern economics, gives the theoretical framework and implementation steps for improving business management efficiency. Secondly, from the design management stage, the formulation of the management process and the actual operation, three key technologies are given to improve the efficiency of enterprise management. Finally, verify the correctness and feasibility of management methods through the implementation and application in enterprises to determine the role of modern economics in the promotion of enterprise management efficiency.

\section{REFERENCES}

[1] Khan M A . MirowskiPhilip and Nik-KhahEdward, The Knowledge We Have Lost in Information: The History of Information in Modern Economics (New York: Oxford University Press, 2017), pp. 298, \$34.95 (hardcover). ISBN: 9780190270056.[J]. Journal of the History of Economic Thought, 2019, 41(3):451-455.

[2] ŁęgowikMałolepsza, Małgorzata, Sałek, Robert, Bubel D, et al. DISRUPTIONS OF THE FLOW OF INFORMATION IN BUSINESS MANAGEMENT[J]. Journal of Clinical Investigation, 2016, 113(9):1271-1276.

[3] Kleef J A G V, Roome N J. Developing capabilities and competence for sustainable business management as innovation: a research agenda[J]. Journal of Cleaner Production, 2007, 15(1):38-51.

[4] Haberman H, Danes S M. Father-Daughter and Father-Son Family Business Management Transfer Comparison: Family FIRO Model Application[J]. Family Business Review, 2010, 20(2):163-184.

[5] Schrepp M, Held T, Laugwitz B. The influence of hedonic quality on the attractiveness of user interfaces of business management software[J]. Interacting with Computers, 2006, 18(5):10551069.

[6] Chen C, Okayama H. High-efficiency transformation of mammalian cells by plasmid DNA.[J]. Molecular and Cellular Biology, 1987, 7(8):2745-2752.

[7] Li G, Shrotriya V, Huang J , et al. High-efficiency solution processable polymer photovoltaic cells by self-organization of polymer blends[J]. Nature Materials, 2005, 4(11):864-868.

[8] Pitt J , Schaumeier J , Artikis A . Axiomatization of Socio-Economic Principles for Self-Organizing Institutions: Concepts, Experiments and Challenges[J]. ACM Transactions on Autonomous and Adaptive Systems, 2012, 7(4):39.1-39.39.

[9] Just H R E. The Potential for Transition to Paid Extension: Some Guiding Economic Principles[J]. 
American Journal of Agricultural Economics, 2001, 83(3):777-784.

[10] Nyberg A J, Pieper J R, Trevor C O. Pay-for-Performance's Effect on Future Employee Performance: Integrating Psychological and Economic Principles Toward a Contingency Perspective[J]. Journal of Management, 2016, 42(7):págs. 1753-1783. 